\title{
IMUNIDADE INDUZIDA PELA USO COMBINADO DE VACINA ATENUADA (ESTIRPE MASSACHUSETTS) E VACINA INATIVADA EXPERIMENTAL (VARIANTE BR-I) CONTRA O DESAFIO COM ESTIRPE VARIANTE BRASILEIRA DO VÍRUS DA BRONQUITE INFECCIOSA AVIÁRIA
}

\author{
IMMUNITY INDUCED BY THE COMBINED USE OF ATTENUATED VACCINE \\ (MASSACHUSETTS STRAIN) AND INACTIVATED EXPERIMENTAL VACCINE (BR-I \\ VARIANT) AGAINST CHALLENGE WITH BRAZILIAN VARIANT OF AVIAN \\ INFECTIOUS BRONCHITIS
}

\author{
R. M. DOS SANTOS ${ }^{1}$, K. R. SILVA ${ }^{1}$, P. D. LOPES $^{1}$, F. S. FERNANDO ${ }^{1}$, M. M. BORZI ${ }^{1}$, \\ M. F. S. MONTASSIER ${ }^{1}$, C. H. OKINO ${ }^{1}$, H. J. MONTASSIER ${ }^{1}$
}

\begin{abstract}
RESUMO
Há atualmente no Brasil, uma predominância de infecções causadas por estirpes do VBI classificadas no genótipo variante (BR-I), que revelam diferenças marcantes de antigenicidade com relação à estirpe vacinal Massachusetts, rotineiramente usada em nosso país. Isso resulta em uma baixa imunidade-cruzada e consequentemente em um menor nível de proteção contra isolados desse genótipo. O propósito deste trabalho foi testar uma vacina inativada contendo uma estirpe variante do VBI pertencente ao genótipo BR-I, e avaliar o estado de proteção induzido por esta vacina em combinação com a vacina atenuada Massachusetts em aves desafiadas com estirpe homóloga. Foram testadas aves SPF distribuídas em três grupos: grupo A (aves vacinadas ao $1^{\circ}$ dia de idade com vacina atenuada comercial, revacinadas com 14 dias de idade com vacina inativada experimental e desafiadas aos 35 dias de idade); grupo B (aves não vacinadas e desafiadas aos 35 dias de idade); grupo C (controle). As aves de cada grupo foram sacrificadas aos 3, 7 e 11 dias pós-infecção, para colheita de amostras de traquéia, rins, soro e lágrima, e posteriormente avaliação histopatológica e das respostas imunes humoral(RIH) pelo ELISA e celular(RIC) pela expressão de genes de RIC. Os resultados deste estudo demonstraram que esse esquema imunoprofilático induziu aumentos significativos nos níveis de anticorpos lacrimais e séricos do isótipo $\operatorname{IgG}$ anti-VBI e também na expressão dos genes relacionados às respostas imunes cito-mediadas, (CD8 e da Granzima A), nas aves vacinadas, que se mostraram associados com a diminuição de lesões histológicas e uma menor carga viral na traqueia e rins das aves vacinadas e desafiadas. Concluiu-se que as RIH e RIC de memória conferidas pela vacinação combinada da estirpe atenuada Massachusetts e da variante IBVPR-05 induziu um estado de proteção efetivo contra a infecção por esta variante, tendo o potencial de proporcionar proteção contra outras variantes do VBI.
\end{abstract}

PALAVRAS CHAVES: CORONAVÍRUS. PATOTIPO. ORNITOPATOLOGIA.

ÁREA TEMÁTICA: Doenças infecciosas 